\title{
Feeding aspects of Leporinus amblyrhynchus (Characiformes: Anostomidae) in the first stages of formation of a Neotropical reservoir, Brazil
}

\author{
Fernando Pereira de Mendonça*, Norma Segatti Hahn** \\ and Valdirene Esgarbosa Loureiro-Crippa***
}

Diet and feeding activity of Leporinus amblyrhynchus before, during and after the damming of the rio Corumbá (Goiás State March 1996 to February 1998) were investigated. The diet, evaluated using the Feeding Index (IAi), showed that this species presents an invertivore feeding habit, preying on basically Chironomidae larvae. The feeding activity, estimated using the quantity of food in the stomach during a 24-hour cycle, showed that the feeding occurs mainly in the daytime. Considering the feeding aspects of this species during the formation of the reservatório of Corumbá there were small variations in the parameters (diet and feeding activity) dealt in this study.

Neste estudo, foram avaliadas a dieta e atividade alimentar diária de Leporinus amblyrhynchus, antes, durante e após o represamento do rio Corumbá, GO (março 1996 a fevereiro 1998). A dieta, avaliada pelo Índice Alimentar (IAi) mostrou que esta espécie apresenta hábito alimentar invertívoro, consumindo basicamente larvas de Chironomidae. A atividade alimentar diária, estimada pela quantidade de alimento nos estômagos, evidenciou tratar-se de uma espécie basicamente diurna que forrageia preferencialmente nos períodos de maior intensidade luminosa. Tanto a alimentação quanto o comportamento na tomada do alimento aparentemente não foram afetados pelo impacto causado pelo represamento do rio Corumbá.

Key words: Feeding ecology, invertivory, freshwater.

\section{Introduction}

Leporinus is the largest genus in Anostomidae, both in number of species and number of individuals, in the fluvial basins where it occurs. The species of this genus present a close anatomical similarity, which infers a widely distributed natural group (Garavello, 1979).

According to Garavello \& Britski (1987), Leporinus amblyrhynchus is widely distributed in the upper rio Paraná and does not occur below the former Sete Quedas (inundated waterfalls) or in the rio Paraguay. In addition to the work cited above, the few references found in the literature to this species refer to fish fauna surveys (FUEM-Nupélia/Itaipu Binacional, 1990) and natural feeding habits (Callisto et al., 2002). In the area of the reservatório of Corumbá (during the study period), this species had high biomass values (pers. obs.). However, its commercial value is low.
Large dams negatively influence the interactions of aquatic organisms, thus compromising the fish fauna in its bio-ecological aspects, mainly concerning feeding and reproduction. According to Agostinho et al. (1999) some fish species respond quickly to impoundment, whereas others respond only after years or decades, dependent to their trophic nature. These authors conclude that the effects of damming on structural and functional characteristics of lotic ecosystems can be established by monitoring studies carried out before and after this intervention. In this sense, although countless reservoirs have been constructed in Brazil, ecological studies of the fish fauna, mainly those that deal with the influence of damming on diet and the resulting trophic alterations, are rare. Mérona et al. (2001), Gama \& Caramaschi (2001), Ferreira et al. (2002), Cassemiro et al. (2002) and Albrecht \& Caramaschi (2003a, b), may be cited. These studies contribute to management and conservation programs in this environment and

\footnotetext{
*Programa de Pós-Graduação em Biologia Tropical e Recursos Naturais - INPA/UA, Manaus, Amazonas, Brazil.

**Núcleo de Pesquisas em Limnologia, Ictiologia e Aquicultura (Nupélia) da Universidade Estadual de Maringá, Av. Colombo 5790, 9020900 Maringá, Paraná, Brazil. e-mail: hahnns@ nupelia.uem.br

***Programa de Pós-Graduação em Ecologia de Ambientes Aquáticos Continentais - Nupélia/UEM. e-mail: loureiro@ nupelia.uem.br
} 
should lead to the establishment of general fish fauna patterns in Brazilian environments subjected to this type of impact.

This study is part of a large-scale project that had as its objective the monitoring of alterations to the fish fauna before, during and after the formation of the reservatório de Corumbá. Natural feeding data and the feeding activity of Leporinus amblyrhynchus (during this transition process) is presented here in order to answer the following questions: 1) What is the feeding strategy of this species? 2) When does the greatest feeding occur? 3) How did the damming influence these aspects?

\section{Material and Methods}

The rio Corumbá Basin comprises $34,000 \mathrm{~km}^{2}$, while the river, which flows into the rio Paranaíba, is about $500 \mathrm{~km}$ long.. The rio Paranaíba, together with the rio Grande, form the rio Paraná (Paiva, 1982). Created in September of 1996, the reservatório de Corumbá is located in the upper third of the rio Corumbá. The reservoir encompasses an area of $65 \mathrm{~km}^{2}$ with an average depth of $23 \mathrm{~m}$. Sampling was carried out at seven fixed sites in the main body of the rio/reservatório de Corumbá, before and after impoundment (Fig. 1).

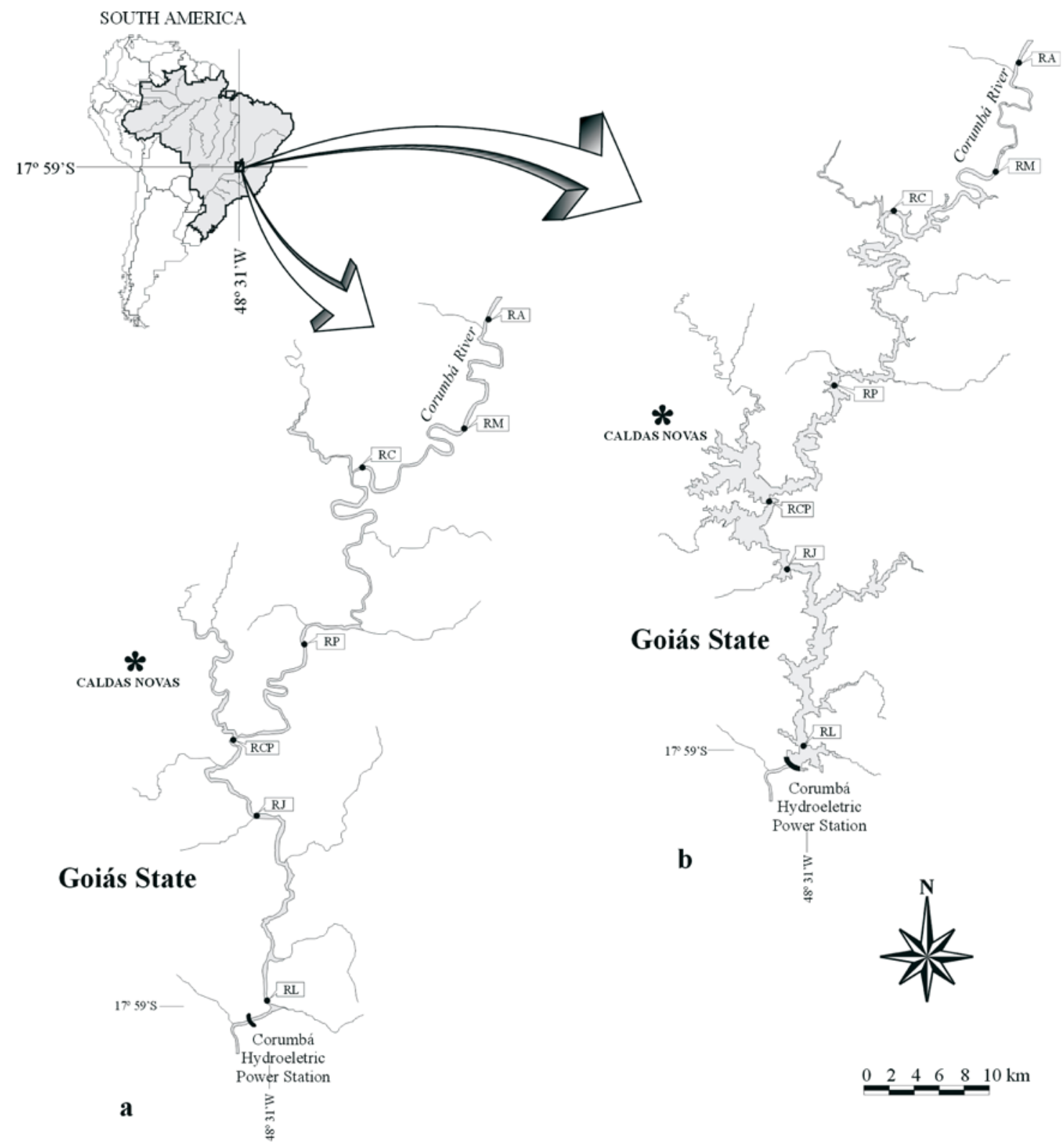

Fig. 1. Location of the study area in the rio Corumbá (a) and reservatório de Corumbá (b), GO. 
Table 1. Occurrence (\%), Volume (\%) and Feeding Index (IAi\%) of the food items in the diet of Leporinus amblyrhynchus, before, during and after damming of the rio Corumbá, Goiás, Brazil. * Values smaller than 0.01 . Values in parentheses indicate the number of stomachs contents. A= Aquatic; $\mathrm{T}=$ Terrestrial.

\begin{tabular}{|c|c|c|c|c|c|c|c|c|c|c|c|c|}
\hline \multirow[b]{2}{*}{ Items } & \multicolumn{3}{|c|}{ Phase I $(\mathrm{N}=60)$} & \multicolumn{3}{|c|}{ Phase II $(\mathrm{N}=71)$} & \multicolumn{3}{|c|}{ Phase III $(\mathrm{N}=11)$} & \multicolumn{3}{|c|}{ Phase IV $(\mathrm{N}=16)$} \\
\hline & 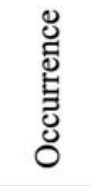 & $\frac{\stackrel{\Xi}{\Xi}}{\partial}$ & ¿ & 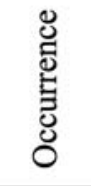 & $\frac{\stackrel{d}{\Xi}}{\stackrel{\Xi}{\circ}}$ & 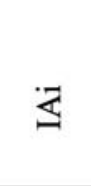 & 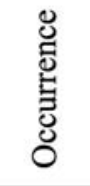 & $\frac{\text { ఏ }}{\stackrel{\Xi}{0}}$ & 【 & 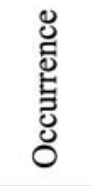 & $\stackrel{\stackrel{O}{\Xi}}{\stackrel{\Xi}{0}}$ & $\mathbb{Z}$ \\
\hline Fish (scales) & 2.81 & 0.34 & 0.07 & 2.97 & 0.88 & 0.21 & & & & 1.22 & 0.05 & $*$ \\
\hline Chironomidae (A) & 15.31 & 66.39 & 73.21 & 16.09 & 43.81 & 56.36 & 16.42 & 67.21 & 70.16 & 19.51 & 40.54 & 42.88 \\
\hline Ceratopogonidae (A) & 6.63 & 0.08 & 0.04 & 5.20 & 0.19 & 0.08 & 1.49 & 0.07 & $*$ & 3.66 & 0.06 & 0.01 \\
\hline Simulidae (A) & 1.79 & 0.12 & 0.01 & 14.80 & 0.71 & 0.84 & & & & & & \\
\hline Empididae (A) & 1.79 & 0.21 & 0.03 & 1.73 & 0.02 & * & 1.49 & 0.02 & * & 1.22 & 0.11 & * \\
\hline Other Diptera (A) & 1.27 & 0.27 & 0.02 & 2.23 & 0.39 & 0.07 & 1.49 & 0.03 & * & 1.22 & 0.01 & * \\
\hline Trichoptera (A) & 12.50 & 4.53 & 4.08 & 8.91 & 7.67 & 5.46 & 7.46 & 1.22 & 0.58 & 6.10 & 3.22 & 1.06 \\
\hline Ephemeroptera (A) & 7.40 & 3.74 & 1.99 & 5.20 & 1.79 & 0.74 & 5.97 & 0.15 & 0.06 & 2.44 & 0.12 & 0.02 \\
\hline Coleoptera (A) & 6.38 & 1.29 & 0.59 & 4.95 & 0.59 & 0.23 & 2.98 & 0.17 & 0.03 & 2.44 & 0.12 & 0.02 \\
\hline Odonata (A) & 0.76 & 0.03 & * & 0.99 & 0.59 & 0.05 & & & & 1.22 & 0.20 & 0.01 \\
\hline Ostracoda & 3.32 & 0.07 & 0.02 & 4.45 & 0.25 & 0.09 & 8.95 & 0.67 & 0.38 & 10.97 & 2.00 & 1.19 \\
\hline Copepoda & 2.81 & 0.06 & 0.01 & 3.96 & 0.08 & 0.03 & 7.46 & 0.89 & 0.42 & 7.32 & 0.14 & 0.06 \\
\hline Cladocera & 2.04 & 0.19 & 0.03 & 1.24 & 0.01 & * & 5.97 & 0.20 & 0.08 & 1.22 & 0.01 & * \\
\hline Hidracarina & 7.40 & 0.18 & 0.10 & 5.69 & 0.10 & 0.05 & 7.46 & 0.07 & 0.03 & 7.32 & 0.38 & 0.15 \\
\hline Oligochaeta (T) & & & & 0.74 & 12.57 & 0.74 & & & & & & \\
\hline Gastropoda (A) & 1.02 & 0.03 & * & 1.24 & 0.19 & 0.02 & 4.48 & 0.17 & 0.05 & & & \\
\hline Bivalvia & & & & 0.99 & 0.67 & 0.05 & & & & & & \\
\hline Testacea & 4.59 & 0.09 & 0.03 & 5.69 & 0.39 & 0.18 & 2.98 & 0.02 & * & 2.44 & 0.01 & * \\
\hline Bryophyte (A) & 1.53 & 0.07 & 0.01 & 0.25 & * & * & 1.49 & 1.77 & 0.17 & 1.22 & 0.46 & 0.03 \\
\hline Hymenoptera (T) & 0.25 & * & * & 0.25 & 0.17 & * & & & & 1.22 & 0.05 & $*$ \\
\hline Lepidoptera (T) & 0.25 & 1.37 & 0.02 & & & & & & & 1.22 & 0.69 & 0.05 \\
\hline Other Insecta (T) & 0.25 & * & * & 0.74 & 0.53 & 0.03 & & & & 1.22 & 0.09 & * \\
\hline Higher plants (remains) $(\mathrm{T})$ & 6.63 & 0.59 & 0.28 & 8.66 & 3.81 & 2.64 & 7.46 & 0.91 & 0.43 & 7.32 & 0.35 & 0.14 \\
\hline Detritus/Sediment & 13.27 & 20.35 & 19.45 & 16.34 & 24.58 & 32.12 & 16.42 & 26.43 & 27.59 & 19.51 & 51.39 & 54.36 \\
\hline
\end{tabular}

Samples were taken in the pre-impoundment phase (phase I-from March to August 1996), in the filling phase (phase II from September 1996 to February 1997) and in the postimpoundment phase (phase III -from March to August 1997 and phase IV -from September 1997 to February 1998) using gillnets $(2.4$ to $16.0 \mathrm{~cm})$. Nets were left for 24 hours and the fish were removed in the morning (8:00, nocturne-matutinal), evening (16:00, diurnal) and at night (24:00, vespertinenocturne).

Fish specimens were measured (SL-cm), weighed (Wt-0.1g) and dissected. Voucher specimens are deposited at the ichthyological collection of the Center of Research in Limnology, Ichthyology and Aquaculture (Nupélia): NUP 1176 (44), rio Corumbá, Goiás State, Brazil, collected by Nupélia staff.

Stomachs with food were preserved in $10 \%$ formalin. Altogether 3219 specimens were collected, but we analyzed 158 stomach contents under a stereomicroscope and the food items were identified to the lowest suitable taxonomic category. Diet composition is described as occurrence and volumetric percentage of each food item, combined in a Feeding Index proposed by Kawakami \& Vazzoler (1980). For large items, the volume was obtained using graduated test tubes and for small items through the compression of the material with a glass slide over a counting chamber under a stereomicroscope; items were grouped and the area occupied evaluated. The total area of food items was considered the total volume $(100 \%)$.

After calculating the Feeding Index, we applied Kendall's concordance coefficient (W) according to Siegel (1975) to evaluate data conformity. We measured the association among several variables, in this case, four different phases of the formation of the reservoir (Statistica version 5.5).

In order to assess the feeding activity, the degree of fullness of each stomach was coded as follows: 0 (empty), 1 (volume <25\%), 2(25\% - 75\%), 3 (75\% - 100\%). Feeding activity patterns were estimated by mean index of stomach fullness in every period of the day. To calculate the mean fullness degree (MFd) we used the equation proposed by Santos (1978). These date were obtained from specimens collected at different times during the 24 hours fishing periods.

\section{Results}

Leporinus amblyrhynchus showed a wide varied diet (24 items), composed mainly by different groups of insects. Microcrustaceans, Arachnida, Annelida, Mollusca, fish scales, and other animal items, complement its diet. Although plants remains (leaf, stalk, seed, etc) were also important, they could not be identified. Chironomidae larvae and detritus strongly dominated the diet during whole period. These items were represented in the phase I respectively by 73.2 and $19.4 \%$ of 

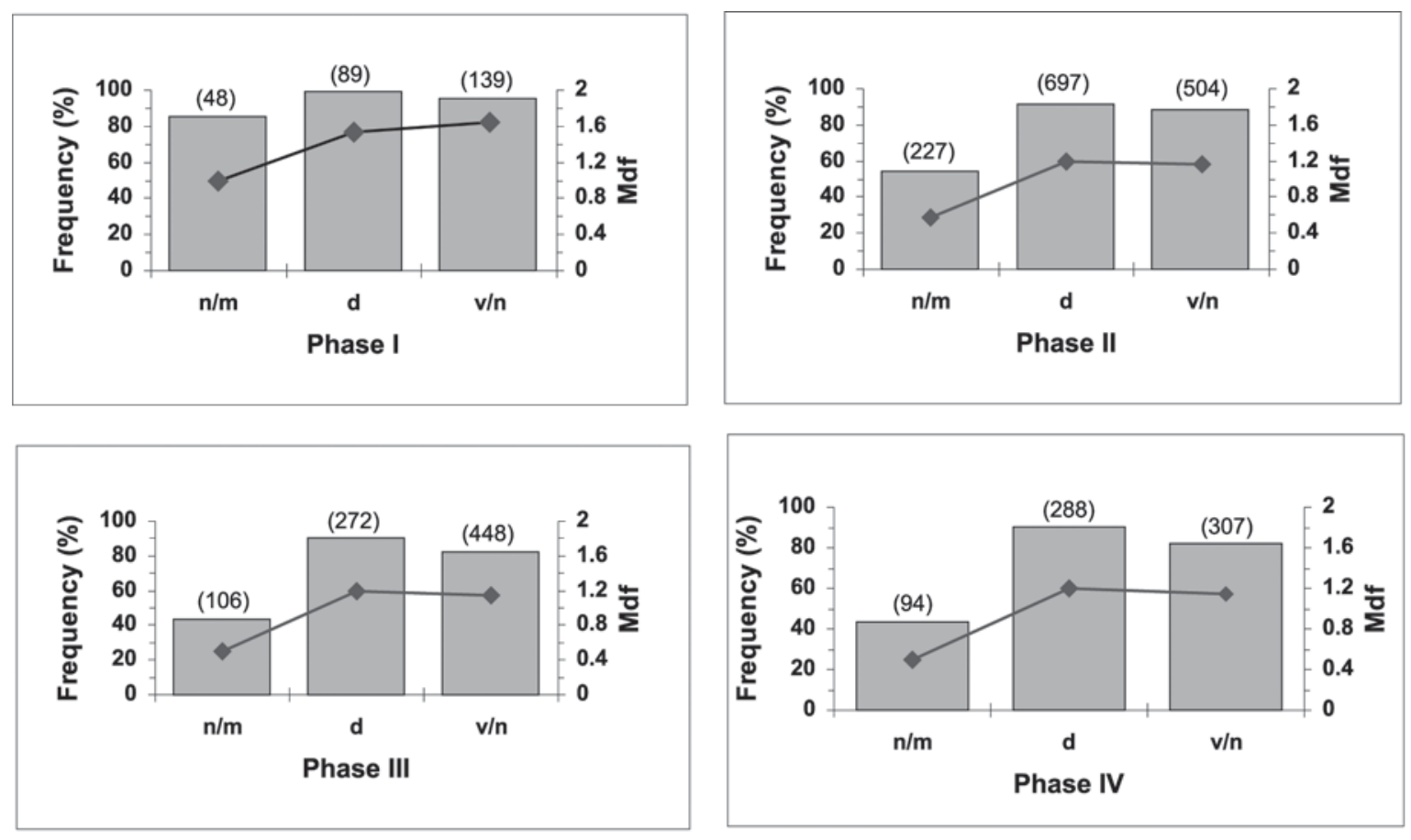

Fig. 2. Variations in the feeding activity of L. amblyrhynchus during formation of the reservatório de Corumbá, Goiás, Brazil. Frequency $(\%)=$ stomachs with food; $M F d=$ medium fullness degree; $\mathrm{n} / \mathrm{m}=$ nocturne matutinal; $\mathrm{d}=$ diurnal; $\mathrm{v} / \mathrm{n}=$ vespertine nocturne.

the Feeding Index, in phase II by 56.4 and $32.1 \%$ and in phase III by 70.2 and $27.6 \%$. However, during the phase IV, these items had similar proportion with values of 42.9 and $54.4 \%$ of the feeding index, respectively (Table 1). Kendall's coefficient $(\mathrm{W}=0.121 ; \mathrm{p}=0.03)$ did not identify significant differences, indicating concordance among the dates, to different phases.

Feeding activity pattern in the pre-impoundment phase was more intense than after impoundment. In phase IV we observed reduction of food in stomach contents. This analysis showed that the species feed mainly during the day and in vespertine-nocturne period (Fig.2).

\section{Discussion}

Due to the high abundance of insect larvae and detritus in the stomach contents of L. amblyrhynchus, the species is characterized here as having an invertivore feeding habit. These data, allied to the sub-inferior position of the mouth, show a strong relationship with the substrate. According to the literature, species of Leporinus generally present omnivous (Santos, 1982; Andrian et al., 1994; Hahn et al., 1998), herbivorous (Luiz et al., 1998) and even piscivorous (Braga, 1990) feeding habits, although bottom-dwellers have also been recorded (Bizerril, 1996). However, the almost exclusive exploitation of Chironomidae larvae (verified in this study) was only recorded for L. obtusidens (Meschiatti, 1998) and $L$. amblyrhynchus (Callisto et al., 2002).
The high consumption of Chironomidae larvae is common among fish because these insects are very abundant and available in freshwater. Higuti \& Takeda (2002) comment that the larvae of these insects can tolerate a wide variety of environmental factors and are apt to inhabit different environments. According to Davies (1976), Chironomidae larvae are well adapted to be the first colonizers of newly flooded areas. They may reach the area either as winged adults or as larvae. Some species can endure the low oxygen concentrations that are likely to occur in new impoundments and have been among the first organisms to appear in these new environments, under a considerable range of conditions (Baxter, 1977).

Temporal variations in diet during the formation of the reservoir were not pronounced since the species restricted its feeding to Chironomidae larvae and detritus. However, Trichoptera larvae, a food constant before and during the damming of the river, almost disappeared from the stomach contents in subsequent periods. This is similar to what was observed for Piabina argentea in a study carried out parallel with this one in the same reservoir (Ferreira et al., 2002). These insects probably did not find conditions favorable to colonization of the new environment because, according to Townsend (1986), Trichoptera larvae (sedentary habit) need hard substrate to fully develop. Another fact to be emphasized is that the consumption of terrestrial earthworms was only in the filling phase of the reservoir. These annelids were probably exposed when the margins were flooded. For other species of Leporinus with a superior mouth (catching food on the surface 
of the water), the filling phase of reservoirs has been marked by the ingestion of termites (Isoptera) that float on the water (Durães et al., 2001; Albrecht \& Caramaschi, 2003a, b; Balassa et al., 2004). The differentiated morphology of the mouth seems to be a powerful mechanism that helps segregate species of Leporinus when several of them occur in the same environment, such as in the reservatório of Manso (Balassa et al., 2004).

The feeding activity of L. amblyrhynchus is considered discontinuous in view of the fluctuations verified in the capture of food during a daily cycle. This pattern did not undergo conspicuous alterations after the formation of the reservoir. The high level of activity recorded in the diurnal period indicates the presence of a daytime-predator species, which intensifies the feeding in the vespertine-nocturne period and decreases it in the nocturne-matutine period. According to Boujard \& Leatherland (1992), when food is always available, the feeding rhythm is synchronized by the photoperiod. This was recorded for species with herbivores and detritivores habits (upper rio Paraná floodplain) by Andrian et al. (1994) and Fugi et al. (1996), respectively. In addition, the circadian feeding rhythm is related to how the prey is detected. In general, predators that depend on visual stimuli decrease consumption with the decrease in luminosity, whereas those that use chemical stimuli do not present large variations with the change in light (Hyatt, 1979). Leporinus amblyrhynchus is included in the first group probably because it presents large eyes, which facilitate the visual predation of moving larvae.

Feeding in fish is controlled by various factors, intrinsic and extrinsic, enabling it, therefore, to be characteristic of one species or individual. Berg (1979) comments that the degree of fullness of the stomach in fish indicates the conditions of the niche, reflecting the level of competition for food, the availability of food organisms, the health of the fish and the abiotic factors. The impact of dams on this activity is one of these factors. The fact that feeding decreased after the damming may be related to lack of its preferential food (Chironomidae) in the first stages of formation of the reservoir and the difficult of the predator to detect the prey in the new environment. This fact probably increased the search time. To Leporinus friderici and L. taeniofasciatus captured in the upper rio Tocantins, the degree of stomach fullness did not change significantly with formation of the reservoir (Albrecht \& Caramaschi, 2003a, b).

It may be concluded that the disturbances caused by the abrupt modification of the environment apparently did not affect the feeding performance of L. amblyrhynchus, at least during the study period, indicating that this species can be a trophic specialist.

\section{Acknowledgments}

We are grateful to Nupélia (Research Nucleus in Limnology, Ichthyology and Aquaculture), Furnas Centrais Elétricas in terms of field study financial support; Conselho Nacional de Desenvolvimento Científico e Tecnológico (CNPq) by personal grants (CNPq proc. NSH: 350538/02-6).

\section{Literature cited}

Agostinho, A. A., L. E. Miranda, L. M. Bini, L. C. Gomes, S. M. Thomaz \& H. I. Suzuki. 1999. Patterns of Colonization in Neotropical Reservoirs, and Prognoses on Aging, Pp. 227-266. In: J. G. Tundisi \& M. Straškraba (Eds.). Theoretical Reservoir Ecology and its Applications. São Carlos, International Institute of Ecology, 585p.

Albrecht, M. P. \& E. P. Caramaschi. 2003a. Feeding ecology of Leporinus friderici (Teleostei; Anostomidae) in the upper Tocantins River, Central Brazil, before and after installation of a Hydroelectic plant. Studies on Neotropical Fauna and Environment, 38(1): 33-40.

Albrecht, M. P. \& E. P. Caramaschi. 2003b. Feeding ecology of Leporinus taeniofasciatus (Characiformes: Anostomidae) before and after installation of a hydroelectic plant in the upper rio Tocantins, Brazil. Neotropical Ichthyology, 1(1): 53-60.

Andrian, I. F., C. R. C. Dória \& G. Torrente. 1994. Espectro alimentar e similaridade na composição da dieta de quatro espécies de Leporinus (Characiformes, Anostomidae) do rio Paraná (22 $\left.10^{\circ}-22^{\circ} 50^{\prime} \mathrm{S} / 3^{\circ} 10^{\prime}-53^{\circ} 40^{\prime} \mathrm{W}\right)$, Brasil. Revista UNIMAR, 16: 97-106.

Balassa, G. C., R. Fugi, N. S. Hahn \& A. B. Galina. 2004. Dieta de espécies de Anostomidae (Teleostei, Characiformes) na área de influência do reservatório de Manso, Mato Grosso, Brasil. Iheringii - Série Zoologia, 94 (1): 77-82.

Baxter, R. M. 1977. Environmental effects of dams and impoundments. Annual Review of Ecology and Systematics, 8: 255-283.

Berg, J. 1979. Discussion of methods of investigating the food of fishes, with reference to a preliminary study of the prey of Gobiusculusflavescens (Gobiidae). Marine Biology, 50: 263-273.

Bizerril, C. R. S. F. 1996. Estrutura trófica de associações ícticas da bacia do rio São João, RJ. Brazilian Archives of Biology and Technology, 39: 509-523.

Boujard, T. \& J. F. Leatherland. 1992. Circadian rhythms and feeding time in fishes. Environmental Biology of Fishes, 35: 109-131.

Braga, F. M. de S. 1990. Aspectos da reprodução e alimentação de peixes comuns em um trecho do rio Tocantins entre Imperatriz e Estreito, Estados do Maranhão e Tocantins, Brasil. Revista Brasileira de Biologia, 50: 547-558.

Callisto, M., V. Vono, F. A. R. Barbosa \& S. M. Santeiro. 2002. Chironomidae as a food resource for Leporinus amblyrhynchus (Teleostei: Characiformes) and Pimelodus maculatus (Teleostei: Siluriformes) in a Brazilian reservoir. Lundiana, 3: 67-73.

Cassemiro, F. A. S., N. S. Hahn \& R. Fugi. 2002. Avaliação da dieta de Astyanax altiparanae Garutti \& Britski, 2000 (Osteichthyes, Tetragonopterinae) antes e após a formação do reservatório de Salto Caxias, Estado do Paraná. Brasil. Acta Scientiarum, 24: 419-425.

Davies, B. R. 1976. The dispersal of Chironomidae larvae: a review. Entomological Society of Southern African. Journal, 39: 39-62. 
Durães, R., P. S. Pompeu \& A. A. L. Godinho. 2001. Alimentação de quatro espécies de Leporinus (Characiformes, Anostomidae) durante a formação de um reservatório no sudeste do Brasil. Iheringia, Série Zoologia, 90: 183-191.

Ferreira, A., N. S. Hahn \& R. L. Delariva. 2002. Ecologia alimentar de Piabina argentea (Teleostei, Tetragonopterinae) nas fases de pré e pós-represamento do rio Corumbá, GO. Acta Limnologica Brasiliensia, 14: 43-52.

Fugi, R., N. S. Hahn \& A. A. Agostinho. 1996. Feeding styles of five species of bottom-feeding fishes of the high Paraná River. Environmental Biology of Fishes, 46: 297-307.

FUEM. Nupélia/Itaipú Binacional. 1990. Ecologia de populações de peixes no reservatório de Itaipu nos primeiros anos de sua formação $7^{\mathrm{a}}$ etapa. UEM, Maringá. Annual Written Report of Research, volume I, 160p.

Gama, C. S. \& E. P. Caramaschi. 2001. Alimentação de Triportheus albus (Cope, 1971) (Osteichthyes: Characiformes) face à implantação do AHE Serra da Mesa no rio Tocantins. Revista Brasileira de Zoociências, 3(2):159170.

Garavello, J. C. 1979. Revisão taxonômica do gênero Leporinus SPIX, 1829 (Ostariophysi, Anostomidae). Unpublished Ph.D. Thesis, Universidade de São Paulo, São Paulo, (3 volumes), 451p.

Garavello, J. C. \& H. A. Britski. 1987. Duas novas espécies do gênero Leporinus Spix, 1829, da Bacia do Alto Paraná (Teleostei, Anostomidae). Comunicações do Museu de Ciências e Tecnologia da PUCRS, Sér. Zool., 44: 115-165.

Hahn, N. S., A. A. Agostinho, L. C. Gomes \& L. M. Bini. 1998. Estrutura trófica da ictiofauna do reservatório de Itaipu (Paraná-Brasil) nos primeiros anos de sua formação. Interciência, 23: 299-305.

Higuti, J. \& A. M. Takeda. 2002. Spatial and temporal variation in densities of Chironomid larvae (Diptera) in two lagoons and two tributaries of the upper Paraná River floodplain, Brazil. Brazilian Journal of Biology, 62: 807-818.
Hyatt, K. D. 1979. Feeding strategy. Pp.71-120. In: Hoar, W. S., D. J. Randall \& J. R. Brett (Eds.). Fish Physiology, vol. III Bioenergetics and Growth. New York, Academic Press, $786 \mathrm{p}$.

Kawakami, E. \& G. Vazzoler. 1980. Método gráfico e estimativa de índice alimentar aplicado no estudo de alimentação de peixes. Boletim do Instituto Oceanográfico, 29: 205-207.

Luiz, E. A., A. A. Agostinho, L. C. Gomes \& N. S. Hahn. 1998. Ecologia trófica de peixes em riachos da bacia do rio Paraná. Revista Brasileira de Biologia, 58: 273-285.

Mérona, B., G. M. Santos \& R. G. Almeida. 2001. Short term effects of Tucuruí Dam (Amazonia, Brazil) on the trophic organization of fish communities. Environmental Biology of Fishes, 60: 375-392.

Meschiatti, A. J. 1998. Ecologia de peixes associados às macrófitas em duas lagoas marginais do rio Mogi-Guaçu. Unpublished Ph.D. Thesis, Universidade Federal de São Carlos, São Carlos, 109p.

Paiva, M. P. 1982. Grandes represas do Brasil. Brasília, Editerra, 292p.

Santos, E. P. 1978. Dinâmica de populações aplicada à pesca e a piscicultura. São Paulo, EDUSP, 129p.

Santos, G. M. 1982. Caracterização, hábitos alimentares e reprodutivos de quatro espécies de "aracus" e considerações ecológicas sobre o grupo no lago Janauacã - AM (Osteichthyes, Characoidei, Anostomidae). Acta Amazonica, 12: 713-739.

Siegel, S. 1975. Estatística não-paramétrica: para as ciências do comportamento. São Paulo, MacGraw-Hill, 350p.

Townsend, C. R. 1986. The ecology of streams and rivers. Australia, Edward Arnold (reprinted) 68p.

Received February 2004 Accepted July 2004 